\title{
The Stock Market Boom and Crash of 1929 Revisited
}

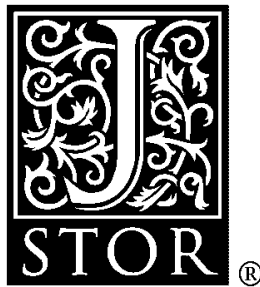

\author{
Eugene N. White
}

The Journal of Economic Perspectives, Vol. 4, No. 2. (Spring, 1990), pp. 67-83.

Stable URL:

http://links.jstor.org/sici?sici=0895-3309\%28199021\%294\%3A2\%3C67\%3ATSMBAC\%3E2.0.CO\%3B2-R

The Journal of Economic Perspectives is currently published by American Economic Association.

Your use of the JSTOR archive indicates your acceptance of JSTOR's Terms and Conditions of Use, available at

http://www.jstor.org/about/terms.html. JSTOR's Terms and Conditions of Use provides, in part, that unless you have obtained prior permission, you may not download an entire issue of a journal or multiple copies of articles, and you may use content in the JSTOR archive only for your personal, non-commercial use.

Please contact the publisher regarding any further use of this work. Publisher contact information may be obtained at http://www.jstor.org/journals/aea.html.

Each copy of any part of a JSTOR transmission must contain the same copyright notice that appears on the screen or printed page of such transmission.

JSTOR is an independent not-for-profit organization dedicated to and preserving a digital archive of scholarly journals. For more information regarding JSTOR, please contact support@jstor.org. 


\title{
The Stock Market Boom and Crash of 1929 Revisited
}

\author{
Eugene N. White
}

I

n trying to explain the 1987 stock market crash, many analysts drew obvious but vague comparisons with the events of 1929 . Newspapers published a chart, reproduced in Figure 1, showing the bull market of the 1920s superimposed on the 1980s. The degree of similarity between the two periods up to the crash was striking. Yet while analysts noted this close correspondence, they drew few inferences from it. Comparisons proved difficult because the crash of 1929 had received little scholarly attention since Galbraith's The Great Crash 1929 (1954).

This paper will sort through many of the hypotheses offered to explain the 1929 boom and bust. Most of the factors cited by historians played trivial or insignificant roles. The central issue is whether fundamentals or a bubble drove the bull market upwards. An econometric resolution of this question is unlikely, for reasons that Flood and Hodrick explain in their contribution to this symposium. However, the qualitative evidence assembled in this paper favors the view that a bubble was present in the 1929 market.

\section{The Conventional Wisdom}

Galbraith's classic book still provides the most commonly accepted explanation of the 1929 boom and crash. He argues that a bubble in the stock market was formed during the rapid economic growth of the 1920s. Galbraith emphasizes the irrational element - the mania - that induced the public to invest in the bull market. The rise in

- Eugene N. White is Associate Professor of Economics, Rutgers University, New Brunswick, New Jersey. 
Figure 1

\section{Common Stock Indices}

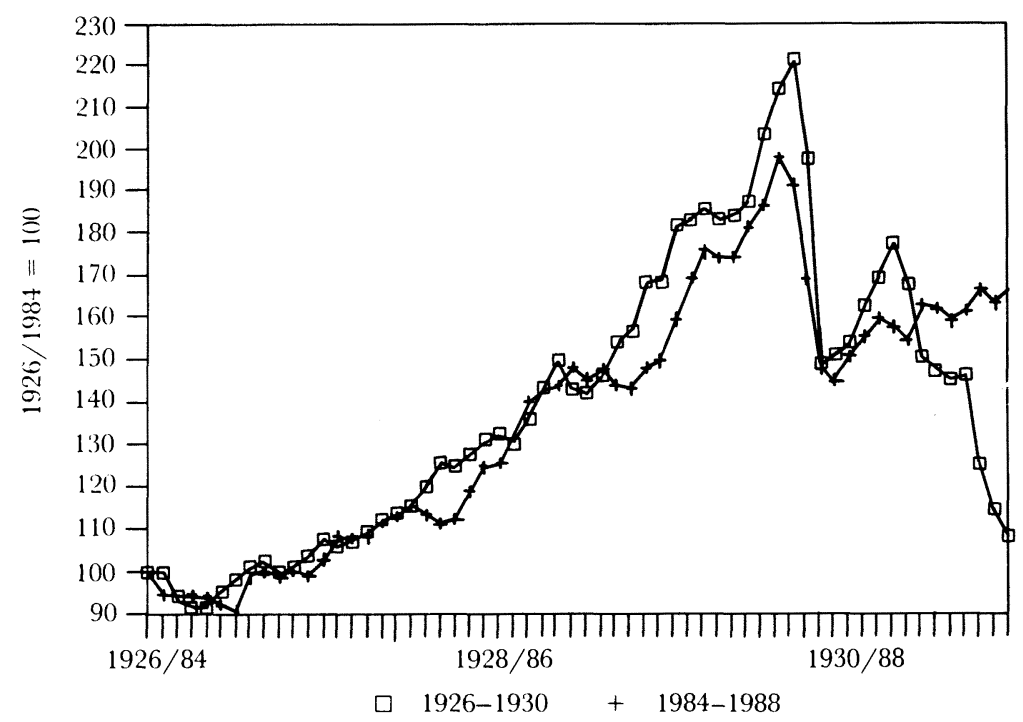

Source: The index for the 1980s is Standard and Poor's 500. The data for the 1920s is found in the Board of Governors of the Federal Reserve System (1943).

the stock market, according to Galbraith's account (1954 and 1988, pp. xii-xiii), depended on "the vested interest in euphoria [that] leads men and women, individuals and institutions to believe that all will be better, that they are meant to be richer and to dismiss as intellectually deficient what is in conflict with that conviction." This eagerness to buy stocks was then fueled by an expansion of credit in the form of brokers' loans that encouraged investors to become dangerously leveraged.

Galbraith and other writers, like Kindleberger (1978), are vague about the causes of the halt in the market, believing that almost any event could have triggered irrational investors to sell. Instead, they focus on the inevitability of the bubble's collapse and suggest several factors that could have exploded public confidence and caused prices to plummet. The vertical price drops on Black Thursday, October 24, and Black Tuesday, October 29, forced margin calls and distress sales of stocks, prompting a further plunge in prices. When the stock ticker ran late, investors panicked and sold their holdings. In the following weeks and months, the market bounced downwards erratically, propelled by and perhaps propelling the depression. ${ }^{1}$

While Galbraith's book makes for compelling reading, there remain many unanswered questions. There is little discussion about how much fundamentals contributed to the bull market and what might have triggered the speculative mania. The argument about easy credit in the form of broker's loans seems strange at a time when the Federal Reserve was pursuing a tight money policy. Furthermore, little has

${ }^{1}$ For the effects of the crash on the depression, see Friedman and Schwartz (1963, pp. 305-308, 334-342) and Romer (June 1988). 
been done to identify the precise role of external events in provoking the collapse. To address these questions, it is necessary to begin with a brief overview of the changes during the 1920s that set the stage for the stock market boom.

\section{The New Economy and Stock Market of the 1920s}

After World War I and a postwar recession, the stability and prosperity of the 1920s appeared extraordinary to contemporary observers. From 1922 to 1929, GNP grew at an annual rate of 4.7 percent and unemployment averaged 3.7 percent (U.S. Department of Commerce, 1975, Vol. I, p. 135 and 226). Part of this growth may be attributed to the emergence of large-scale commercial and industrial enterprises that took advantage of new continuous process technologies. Coordination by the emerging system of modern management, as described by Chandler (1977), produced more efficient vertically-integrated enterprises that captured economies of scale and scope.

The financial needs of these new enterprises altered the face of American capital markets. Regulations imposed on commercial banks in the nineteenth century severely limited their ability to provide large long-term loans, and firms turned to financing their investments out of retained earnings and bond and stock issues. ${ }^{2}$ The market for industrial securities, which first emerged in the 1880s, came of age in the 1920s, as both old and new corporations issued equities to finance new plant and equipment.

Commercial banks did purchase more bonds, but they could not legally trade or acquire equities. To circumvent this restriction, they set up wholly-owned securities affiliates, which permitted them to enter all aspects of investment banking and the brokerage business. Peach (1941) found that the number of affiliates grew rapidly from 10 in 1922 to 114 in 1931 . These affiliates attracted many new customers and became big distributors of stocks and bonds, enabling them to become underwriters. By 1930, commercial banks' security affiliates had obtained roughly half the bond originations. By moving into investment banking through their affiliates, commercial banks were thus able to continue servicing the needs of their corporate customers (White, 1986).

While the securities affiliates catered to a broader clientele than most traditional brokerage houses, many small investors might still have shied away from buying securities, lacking sufficient capital to purchase a diversified portfolio of stocks. This obstacle was eliminated by the investment trusts, which served the same function as mutual funds do today. ${ }^{3}$ According to Carosso (1970), investment trusts grew from about 40 in 1921 to over 750 in 1929.

\footnotetext{
${ }^{2}$ National banks were prohibited from lending more than 10 percent of their capital and surplus to one customer. The effect of this regulation on banks' lending capacity was amplified by strict federal and state limits on branch banking that restricted banks' ability to grow.

${ }^{3}$ Investment trusts were primarily institutions that sold securities to the public and used the proceeds to invest in stocks and bonds. There were two main types: management trusts where managers had discretion over the portfolio and fixed trusts where the portfolio could not be changed.
} 
The growth of the securities market, assisted by the establishment of investment trusts and securities affiliates, allowed firms to substitute stocks and bonds for commercial bank loans. This development began well before the stock market boom, but the pace of change accelerated in the 1920s with the rapid growth of modern industrial enterprise. During this decade, banks found their traditional role as intermediaries sharply reduced. ${ }^{4}$ In response, they sought to increase their fee income by offering new financial services, including trusts and insurance (White, 1984). Most importantly, they increased their role as brokers between the saving public and industry. Banks were familiar with their borrowers and conditioned to monitor their activities. However, many of the new investors they served lacked experience in buying stock and monitoring firms, thus creating a favorable condition for a bubble. ${ }^{5}$

Frederick Lewis Allen (1931) and Galbraith see the stock market bubble beginning in March 1928. This first upward tick is registered in the index of common stocks in Figure 1. In the months of April and May, this index increased 15 percent. In his influential account of the stock market, Allen dates the boom as beginning on Monday, March 5. In the aggregate indices, there is nothing extraordinary about this date. Allen's reason for selecting this day is the five point rise in General Motors' stock, which by the end of the week had increased 7 percent. Other stocks shared this excellent week, most notably RCA, which rose almost 14 percent.

Allen attributes the initial sharp rise in March to the purchases by big bullish speculators, but this increase can be justified by economic developments. The economy had been in a recession until late 1927. When business picked up, the stock market responded. General Motors was attractive because Ford (still a private company) had shut down to retool for the Model A. With its more advanced management and organization, GM was able to take advantage of this opportunity, increasing production and sales and seizing the leading position in the industry. Its management exuded confidence. At the end of the month, GM's president predicted its price would rise from 180 to 225 , and he promised to return to stockholders 60 percent of earnings. 6

The other stock that dominated the New York Exchange was RCA, the purveyor of a new technology. RCA's sales were growing by 50 percent each year. Its prospects, which looked excellent as the economy recovered, were reaffirmed by the release of the company's 1927 annual report in early March 1928. RCA stock was thus quite attractive, but not because it promised to pay high dividends like General Motors. The company had never paid a dividend, nor would it pay one for many years to come. The only reason to buy RCA in the short-run or even the medium-run was the

\footnotetext{
${ }^{4}$ Commercial loans as a percentage of total earning assets of national banks fell from 58 percent in 1920 to 37 percent in 1929 (Currie, 1931).

${ }^{5}$ This appears to have happened in other asset market bubbles. A new group of less sophisticated investors also became active during the South Sea Bubble (Neal, 1990).

${ }^{6}$ Commercial and Financial Chronicle, March 24, 1928, Vol. 126, p. 1988. Other automobile companies and suppliers ranked among the most heavily traded stocks and contributed to a lesser extent to the rise in the stock market indices.
} 
Figure 2

\section{Common Stock Indices}

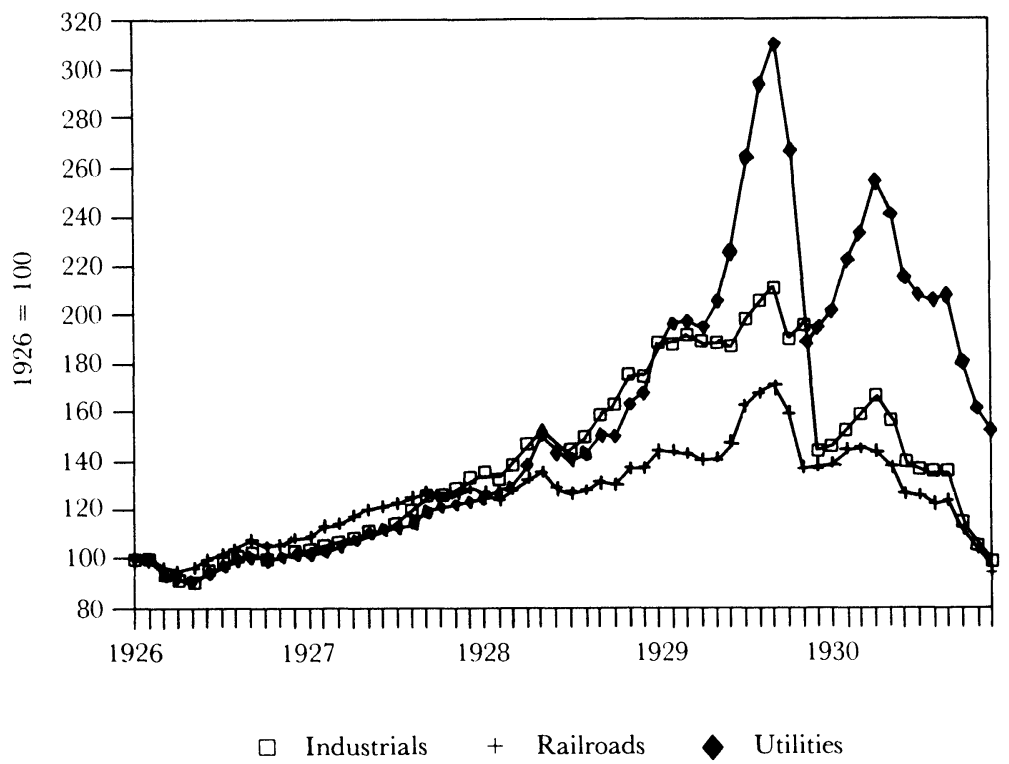

Source: Board of Governors of the Federal Reserve System (1943).

belief that its business would continue to thrive and the price of its stock would increase in the hope of dividends in the distant future. Expectations of dividends from RCA had to be extremely diffuse.

Many other prominent companies that did not pay dividends caught the public's attention, too. These included Radio-Keith-Orpheum, the Aluminum Company of America, and the United Aircraft and Transport Corporation. ${ }^{7}$ Like RCA, these firms used new, developing technologies. The proportion of firms not paying dividends was also high among public utility holdings companies. These included the Commonwealth and Southern Corporation, Electric Bond and Share and the North American Company. The electric utility industry was undergoing a remarkable transformation in the 1920s where consolidation and expansion gave firms great economies of scale in production and transmission. This was another frontier industry with potentially high but uncertain returns.

The attraction of utilities' stocks is revealed in Figure 2 which shows indices for industrials, railroads, and public utilities. The boom in utilities far outstripped industrials, while the relatively stable, established railroads languished. Although previous writers have not concerned themselves with the prominence of public utilities and high-tech stocks, they were a central feature of the bull market.

\footnotetext{
${ }^{7}$ Wigmore (1985) offers a detailed description of the performance of individual firms and industries.
} 


\section{The Role of Fundamentals in the Bull Market of the 1920s}

Although most historians believe that the 1920s bull market was a bubble and concede only a small role for real factors, some contemporary observers attributed most of the market's rise to fundamentals. At the height of the market in August 1929, when many began to fear that there was excessive speculation, Charles Amos Dice (1929) of Ohio State University argued that the higher prices in the stock market were the product of economic fundamentals. Even after the crash in December 1929, Irving Fisher (1930) of Yale retained his conviction that the rise in stock prices was justified and wrote, "My own impression has been and still is that the market went up principally because of sound, justified expectations of earnings, and only partly because of unreasoning and unintelligent mania for buying."

Both Dice and Fisher believed that earnings and dividends would continue to grow rapidly because of great economic improvements they saw in the economy. These changes - the systematic application of science to industry, the development of modern management techniques, and mergers that gained economies of scale and scope-are the same ones that economic historians have emphasized to explain growth in the '20s. Thus, although Galbraith ridiculed Dice and Fisher in the aftermath of the crash, their views cannot be dismissed lightly.

The convictions of Fisher and Dice have more recently found support in the work of Sirkin (1975). He believes that the high stock prices and high price-earnings ratios were a consequence of the expected rapid growth of earnings. Assuming that a price-earnings ratio of 15 would have been normal, Sirkin calculated that earnings would have had to grow at 9 percent for another 10 years in order for the peak $\mathrm{P} / \mathrm{E}$ ratio of 20.4 to have been warranted. Since 9 percent was the average growth rate for 1925-1929, Sirkin concluded that there was no "speculative orgy."

The argument for a fundamental explanation of the stock market boom holds that the rise in stock prices would have been justified by continued economic growth if policy blunders by the Federal Reserve and the Congress had not plunged the economy into a depression. However, given the normal duration of business cycles, it seems unlikely that the boom could have been sustained that long. Furthermore, it is by no means evident that it was appropriate for the public simply to extrapolate from the growth rate of the past few years.

In analyzing the role of fundamentals, researchers have only had annual data, yet this hides some of the key developments of 1928-1929. Quarterly earnings are not available, but White (1989) created a new quarterly index of dividends for the firms in the Dow-Jones Index from 1922 to 1930. In Figure 3, this index and the Dow-Jones Industrial Index are graphed. This figure reveals the remarkable change that overtook the stock market. From 1922 to 1927 dividends and prices moved together, but while dividends continued to grow rather smoothly in 1928 and 1929, stock prices soared far above them.

The behavior of prices and dividends seems to imply that managers did not share the public's enthusiasm. Investors might have bid up stock prices based on an 
Figure 3

\section{Stock Price and Dividend Indices}

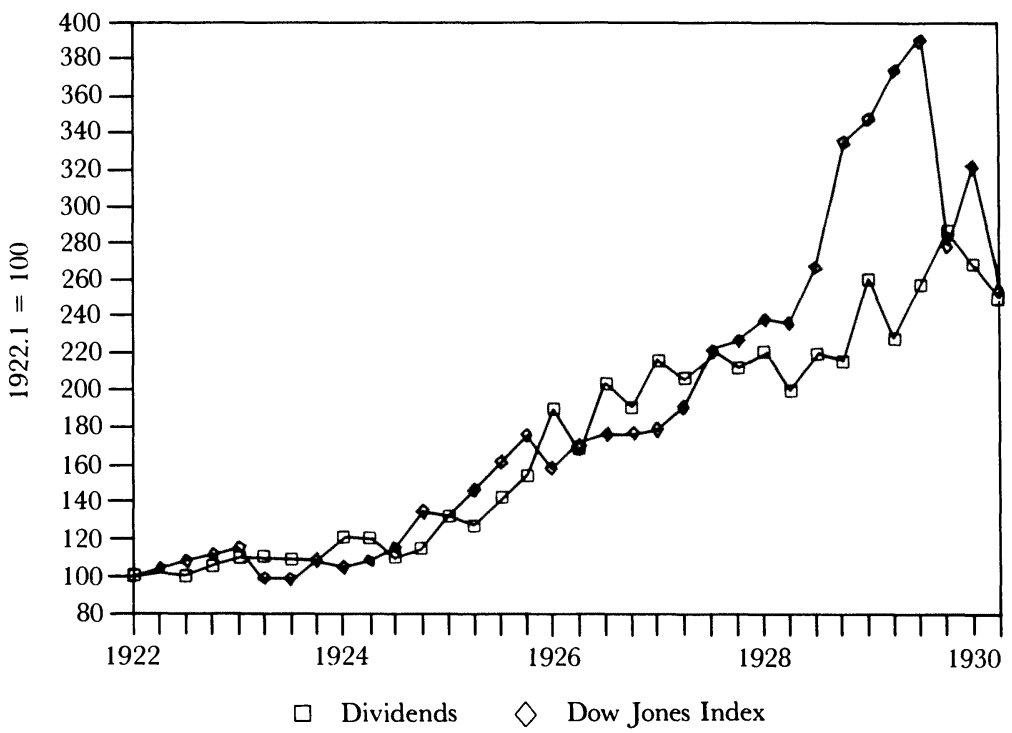

Source: White (1990) and Pierce (1986).

extrapolation of a few years' earnings growth, but managers did not increase dividends as quickly. The failure of dividends to keep pace with stock prices does not, however, necessarily imply the existence of a bubble, as it is generally believed that managers are hesitant to increase dividends unless they perceive a permanent rise in earnings. Yet, the available evidence suggests that many managers did not believe that their earnings would rise sufficiently fast to justify the prices of their stock. ${ }^{8}$ Some executives were alarmed enough to warn the public. In 1928, A. P. Giannini, head of Bancitaly (the future Bank of America) stated that the high price of his bank's stock was unwarranted, prompting a sharp drop. Patterson (1965) has identified other companies where the management publicly stated that the stock was overvalued, notably Canadian Marconi and Brooklyn Edison.

A change in fundamentals may have initiated the boom, but fundamentals probably did not sustain it. The continued disappointment of unrealized dividends and public statements of some managers did not slow the rise in stock prices. This leaves the greater part of the boom to be explained. One favored candidate is easy credit.

\footnotetext{
${ }^{8}$ Marsh and Merton (1987) have offered a model of the dividend behavior for the aggregate stock market. When White (1990) applied this model and forecast dividends for the 1929 boom, he found that the expected dividends differed little from the actual dividends, suggesting that stock prices should not have soared.
} 


\section{Credit and the Stock Market Boom}

Many economic historians believe that the expansion of brokers' loans helped to create the bubble. ${ }^{9}$ Kindleberger argues that stock market credit was a key element in generating the mania. Galbraith sees the ability to purchase stock on margin as a great speculative lure. A buyer needed only to provide a fraction of the required funds, borrow the rest and enjoy the full capital gain less the interest on the borrowed funds. Even Irving Fisher believed that ability to borrow money encouraged "unwise speculation."

It is easy to understand the presumption that a credit expansion fueled the stock market boom by looking at Figure 4. This graphs an index of the New York Stock Exchange's brokers' loans and an index of stock prices. These two indices are almost indistinguishable, especially for the period of the boom. While this coincidence may seem convincing, it is hard to understand how credit to buy stock could have been easy when credit in general was tight in the second half of the 1920s. The Federal Reserve pursued a contractionary policy beginning in January 1928, with open market sales and a rise in the discount rate from $3 \frac{1}{2}$ to 5 percent. By Hamilton's (1987) measurement, money was tight during the whole course of the boom. In 1928 and 1929, high-powered money and the consumer price index fell and M1 grew only slightly in 1929.

The Federal Reserve's tight money policy during these years was a consequence of its fears about the flow of credit to the stock market. The Federal Reserve had always been concerned about excessive credit for speculation. Its founders were influenced by the real bills doctrine and had hoped the new central bank's discounting activities would channel credit away from "speculative" and towards "productive" activities. ${ }^{10}$ Although there was general agreement on this issue, the stock market boom created a severe split over policy.

The Federal Reserve Board believed that "direct pressure" could be used to rechannel credit away from speculation. To curb stock market speculation, the Board wanted member banks making loans on securities to be denied access to the discount window. The Federal Reserve Bank of New York contended that the Federal Reserve could not refuse to discount otherwise eligible assets for its individual members and that it was impossible to control credit selectively. It argued that speculation could only be reduced by raising the discount rate. Between February 1929 and August 1929, the directors of the Federal Reserve Bank of New York frequently voted to raise the discount rate, only to be turned down by the Board, which reaffirmed its policy of direct pressure.

\footnotetext{
${ }^{9}$ When an investor bought stock on margin, his broker usually paid the difference by contracting a broker's loan from a bank that was collateralized by the stock. Call loans were the most important type of brokers' loans. These loans had a daily call option and floating interest rate. Of lesser importance were time loans that had a fixed maturity and interest rate.

${ }^{10}$ The real bills doctrine asserted that banks should invest primarily in short-term commercial bills that represented actual production. The Federal Reserve Act attempted, in part, to implement this doctrine by limiting the types of assets that were eligible for discounting at the Federal Reserve banks. See West (1977).
} 
Figure 4

\section{Stock Prices and Brokers' Loans}

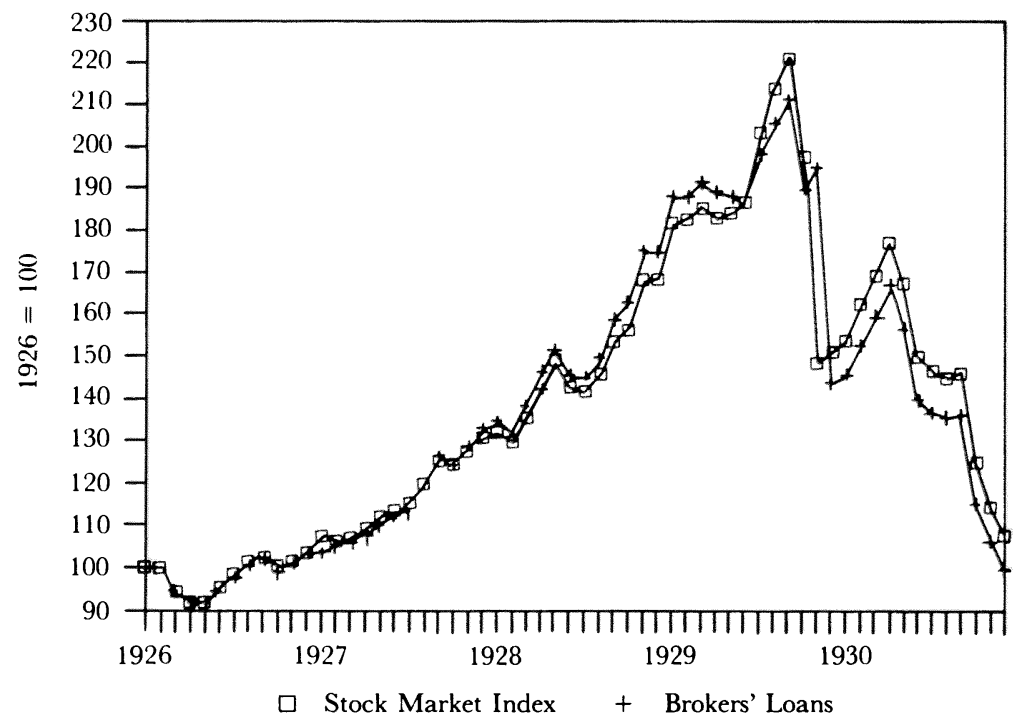

Source: Board of Governors of the Federal Reserve system (1943) and the New York Stock Exchange Year Book (1931).

Looking at the rapid growth of brokers' loans in 1929, the Federal Reserve Board was understandably frustrated and angry, but it was not because its member banks failed to comply. Loans to brokers by New York member banks on their own account reached a peak at the end of December 1927, and then declined. Loans made by these banks on account for out-of-town banks also grew slowly during the boom. The rapid growth occurred in loans from private investors, corporations and foreign banks in Europe and Japan, which quickly substituted for bank loans.

Historians acknowledge this flexibility of credit, and Kindleberger identifies the rising supply of brokers' loans from non-bank sources as responsible for fueling the boom. This interpretation, however, ignores the rise in the interest rates on brokers' loans. Figure 5 shows the movements in the discount rate, the commercial paper rate and the two rates for brokers' loans. After moving together with the other two rates for 1926 and 1927, the call and time rates increased sharply. Although the differentials were not constant for the whole boom, they remained very large, suggesting that it was the rising tide of speculation that demanded funds, not any independent creation of credit. $^{11}$

The interest rate differentials also suggest that lenders no longer regarded brokers' loans as very safe and insisted on a substantial premium. This is buttressed by Smiley and Keehn's (1988) finding that margin requirements began to rise sharply in October 1928, soon reaching historic levels. While borrowers may have been quite

\footnotetext{
${ }^{11}$ A simple econometric model of the market for brokers' loans (White, 1990) finds no evidence for a supply-side shift that could have fueled speculation.
} 
Figure 5

Interest Rates

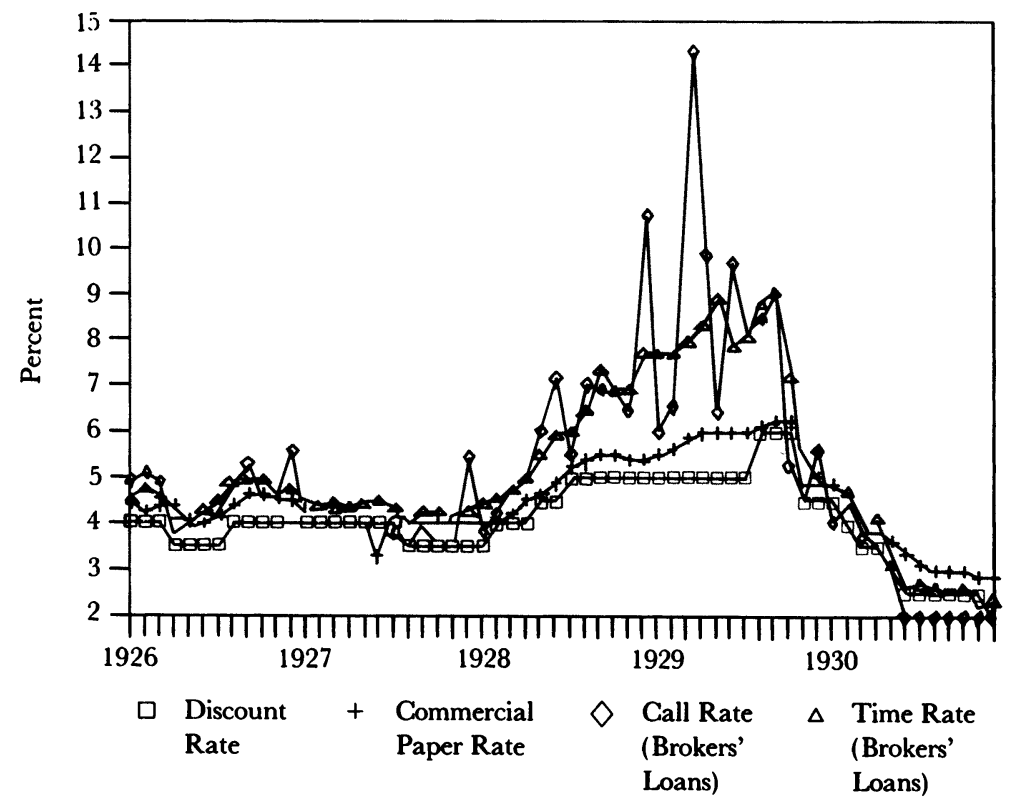

Source: Board of Governors of the Federal Reserve System (1943).

sanguine about the rise in the market, lenders did not completely share their optimism.

Brokers' loans did not contribute to the stock market boom. Instead, the demand for credit to buy stock pulled funds into the market, forcing a major reallocation of credit in the money and capital markets. ${ }^{12}$ As the call rate rose, there was a sharp decline in commercial paper. In September $1927, \$ 600$ million in commercial paper was outstanding. By September 1929, according to the Board of Governors of the Federal Reserve's Banking and Monetary Statistics (1943, pp. 465-466), it had declined to $\$ 265$ million. Ivan Wright (1929) discovered that commercial banks provided more loans and discounts to firms that had previously relied on the commercial paper market. These firms' former lenders moved into the call market from which banks had been discouraged by the Federal Reserve. The growth in the new issues of domestic stock increased dramatically, while issues of domestic bonds and notes declined from $\$ 3183$ million in 1927 to $\$ 2078$ million in 1929 and foreign securities fell even more from $\$ 1338$ million to $\$ 673$ million. This evidence reaffirms the independent character of the stock market bubble, whose demand for funds and new issues forced major changes in other financial markets.

\footnotetext{
${ }^{12}$ The stock market boom also had a powerful effect on the demand for money, via the demand for transactions balances to buy stocks. Field (1984) has shown that this caused money markets to tighten further as the boom progressed, misleading the Federal Reserve as to the actual effect of its policies.
} 


\section{Testing for A Bubble in the Stock Market}

If loans to buy stock were not cheap and the role of earnings and dividends was restricted, the surge in stock prices requires an alternative explanation. The surviving candidate is that a bubble appeared in the stock market. Although a large literature has explored the existence of bubbles in financial markets, the econometric identification of bubbles is elusive. ${ }^{13}$ A large literature has explored existence of bubbles in financial markets. The models consider the possibility that the price of a stock may not reflect simply its market fundamentals - that is, the expected present value of all future dividends - but may also include some bubble element. Flood and Hodrick provide an exposition of the basic model in this journal. As they and Hamilton (1986) have pointed out, the problem with bubble tests is that they specify a set of market fundamentals and then ascribe any leftover price movements to a bubble. Thus, one may perceive a bubble only because the model was not correctly specified.

In addition to this problem, these empirical tests have relied on annual data for stock prices and dividends. Annual data may be sufficient to detect long-term bubbles, but they will not pick up the 1928-1929 boom and bust. Furthermore, the data employed is all aggregate. As Figure 2 showed, not all stocks were caught up in a wave of speculation. Railroad stocks were excluded from the boom, while utilities were the favorites of speculators. Fisher's equally weighted stock price index (1966) reached its peak in February 1929, indicating that the majority of stocks on the New York Exchange did not fully participate in the boom. Thus, aggregate annual data may not capture a possible bubble in 1928-1929, even if the model is correctly specified.

Although dividend data for this period is almost exclusively annual, price data is more abundant. Using the daily and monthly Dow Jones Industrials index, Santoni (1987) and Santoni and Dwyer (1989) have performed runs tests and Box-Pierce tests on the estimated autocorrelations for the period of the boom. They found that prices followed a random walk and that there was no evidence for the market feeding on itself; however, as Blanchard and Watson (1982) and Shiller and Perron (1985) have shown, the power of these tests can be very low.

While it may be currently impossible to determine econometrically whether a bubble was present in the 1928-1929 stock market, considerable qualitative evidence suggests that the necessary conditions were present. Blanchard and Watson (1982) posit that bubbles are likely to appear when fundamentals become difficult to assess. Although they believe that bubbles are unlikely in blue chip stocks, the stock market of the 1920s had characteristics favorable to the emergence of bubbles. Fundamentals became difficult to judge because of major changes in industry. In automobiles, there was an abrupt shift from the dominance of the proprietary Ford Motor Co. to the more modern General Motors. While investors had every reason to expect earnings to grow, they lacked the means to evaluate easily the future path of dividends. RCA was also a highly successful firm in a new industry whose technology was rapidly

\footnotetext{
${ }^{13}$ See Diba and Grossman (1988), Campbell and Shiller (1988) and the related literature on stock market volatility, including Shiller (1981), Mankiw, Romer and Shapiro (1985), and Kleidon (1986).
} 
changing. Not only were RCA's prospects uncertain but the absence of any dividend record left investors with little to judge fundamentals. Other high-tech firms and utilities, with no history of dividends and possibly brilliant futures, became favorites in the boom even though their fundamentals were difficult to assess.

The overall sophistication of investors was weakened by the influx of new people into the market. Since the turn of the century, the demands of industrial finance and regulation had reduced the role of commercial banks and increased the need to sell stock to the general public. Even before the boom began, many people who had never bought stock before entered the market. One identifiable group of new investors was women (McMullen, 1930), whom brokers catered to with special programs and even their own rooms to watch the ticker tape. Women's magazines carried articles on how to buy stocks, including John Raskob's famous interview (Crowther, 1929) entitled "Everybody Ought to be Rich." While these changes are not easy to quantify, they do provide qualitative evidence on the existence of conditions that enhanced the likelihood of a bubble appearing in the stock market.

The speculative urge that had propelled the market upwards began to falter in the autumn of 1929. The decline and then sudden plunge of the market has been well-chronicled, but the number and variety of explanations for the crash have left its causes unclear.

\section{Causes of the Crash}

The students of 1929 have had a tendency to minimize the importance of any single factor precipitating the crash. They treat the demise of the bull market as an endogenous collapse of expectations. Galbraith and Kindleberger argue that the stock market was inherently unstable and anything could have shattered the public's confidence. Yet something did convince investors that their expectations of future price increases were no longer justified. Contemporary pundits offered many explanations, including the excessive issues of new stock, decisions by government regulators, the Smoot-Hawley tariff, foreign stock markets, and declining brokers' loans. This section considers each of these and finds them to be minor or irrelevant factors in the crash. Instead, the downturn in the business cycle, made more severe by tight credit, prompted a revision in expectations.

The rising stock market made it attractive for companies to issue new stock. In 1927 , $\$ 1474$ million of new preferred and common shares were issued. By 1929, this reached $\$ 5924$ million, with over $\$ 1$ billion of shares issued in September. As in other bubbles, where speculation began with a nearly fixed supply of an asset, rapid price rises called forth significant additions to the supply. Fred I. Kent (Fisher, 1930, pp. 48-49) suggested that the issue of new securities overwhelmed the market. But while these increases were large, they were modest in comparison to the total supply. The value of the stocks listed on the New York exchange alone was $\$ 89.7$ billion on September 1 . In response to this increment in supply, prices might have sagged but not collapsed. New stock issues were, at most, a small contributing factor to the crash. 
Utilities were among the high-flying stocks of 1929. Some pundits claimed that Massachusetts' refusal on October 11 to allow Boston Edison to split its stock sent a threatening signal to the market. Regulators denied the request on the grounds that it would encourage further speculation, and they began a rate inquiry. If the crash began in the utilities because of this announcement, there was no sign of anticipation or reaction in the Dow Jones indices. The index for utilities and the index for industrials dropped by the same proportion, under 1 percent on that day. While the regulatory decision was upsetting to the Boston Edison stockholders, it must be considered an irrelevant factor in the crash.

In most explanations of the Great Depression, the passage of the Smoot-Hawley tariff is regarded as a key factor in disrupting the international economy. Fisher (1930) believed that anticipation of the tariff contributed to the crash, while Jude Wanniski (1978) gives the tariff sole responsibility for the market's collapse. If the tariff was a key factor, it should have especially hurt the export industries through decreased foreign demand by the operation of the foreign trade multipliers and foreign tariff retaliation. Nontradeables and import-competing industries would not have sustained the same injury and might have benefited. After identifying industries as exporters, import-competing or nontradeables, White (1990) finds that the stocks of all groups declined approximately the same percentage at the time when the tariff's passage was assured. There is thus no evidence to support of the view that the Smoot-Hawley tariff significantly contributed to the crash. ${ }^{14}$

The failure in Great Britain of the business and financial empire of Clarence Hatry on September 20,1929, has been cited by Galbraith, Patterson, and Fisher as an important shock to first the London and then the New York market. Fisher based his argument on his own stock price indices that showed London prices fall sharply and in advance of New York's. However, this drop does not square with the broad monthly index published by The Bankers' Magazine (1931). This index is depicted in Figure 6 along with indices for the New York and Berlin exchanges. By October 18, after Hatry and before the Wall Street plunge, the index had fallen 2.8 percent. This is far less than the drop Fisher found and hardly alarming, given larger earlier declines. Furthermore, American Railway stocks accounted for almost half of the 2.8 percent fall. The London market simply reacted to the New York market.

In comparison to the worldwide bull markets of the 1980s, foreign stock markets in the 1920s often moved independently of New York, as seen in Figure 6. There was no boom in the Berlin market, which began falling in early 1928. The German decline stemmed partly from the reduction in post-World War I American lending, as investors turned their sights on New York, and partly from the tight monetary policies

\footnotetext{
${ }^{14}$ The assumption that the Smoot-Hawley tariff played a key role in beginning the Great Depression has recently been challenged by Eichengreen (1986). He finds that the direct and feedback effects of the tariff on the American economy were small and its stimulus to new foreign tariffs was slight. Eichengreen believes that the only way in which the tariff contributed to the depression was by increasing the American balance of payments surplus, thereby putting additional strain on other countries' ability to adjust under the gold standard. His work suggests that the market had even less reason to consider the passage of the Smoot-Hawley tariff singularly bad news.
} 
Figure 6

European Stock Exchanges

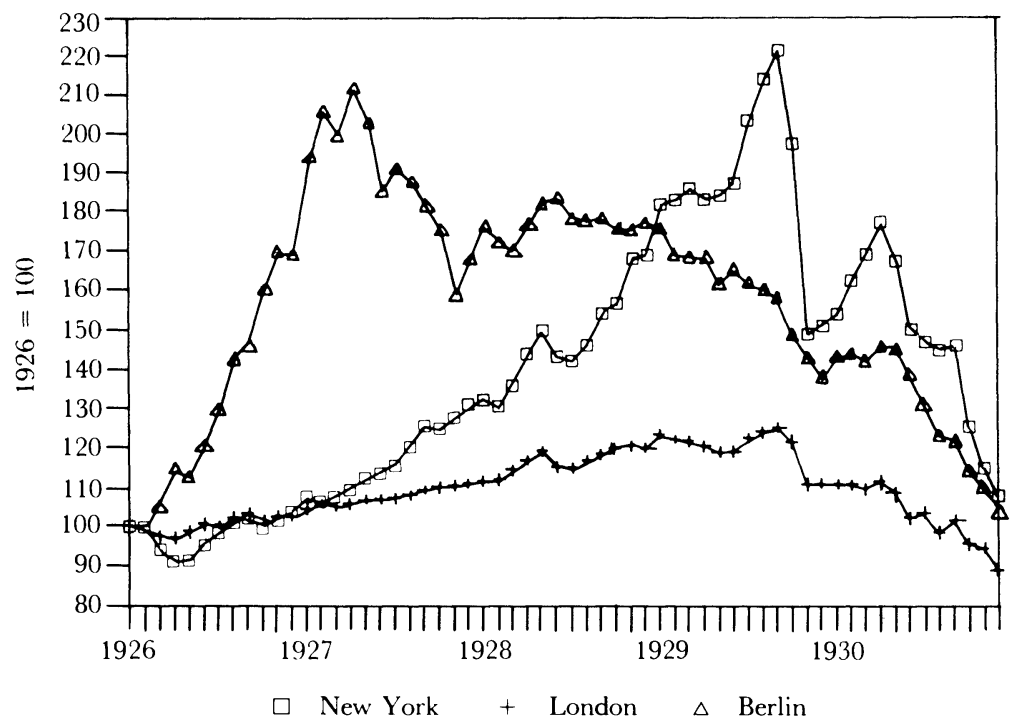

Source: Board of Governors of the Federal Reserve System (1943), The Bankers' Magazine (June 1931), and the Federal Reserve Bulletin (May 1931).

of the Reichsbank. The weak stock prices in European markets before October 1929 were more a consequence of the stock market boom than a cause of its demise. The Federal Reserve's tight monetary policy forced Great Britain and Germany to raise their discount rates to counter short-term capital's attraction to New York's high interest rates (Clarke, 1967). For months, the New York Fed had wanted a higher discount rate to tame the stock market. Finally the Board allowed it to raise its discount rate from 5 percent to 6 percent on August 9. As Hamilton (1987) has shown, falling prices made real rates much higher in 1929. Responding to a deterioration in their balance of payments, the British increased their bank rate again in September.

This general rise in interest rates did not have any immediately observable effects on brokers' loans. Weekly reports of brokers' loans show that they peaked on October 9 at $\$ 3941$ million and then fell to $\$ 3823$ million on October 23 . This decline was not a signal of some catastrophe, as there had been larger temporary drops before. As in the months during the boom, brokers' loans responded rather than drove the stock market's decline.

The inadequacy of these explanations leads back to the question whether any abrupt change in dividends or earnings might have set off the crash. The aggregate figures give no hint of new developments. The quarterly dividends of the Dow-Jones industrials show healthy increases in late 1929, rising 12.8 percent in the third quarter and 11.6 percent in the fourth. The first drop of 6.3 percent appears only in the initial quarter of 1930 . 
However, there was evidence of an oncoming recession. In the absence of any quarterly earnings, the Federal Reserve's index of industrial production may be used as a proxy. This first dropped in July $1929 .{ }^{15}$ In August and September, some of the Federal Reserve's other indices began to fall. This mixed news and rising real interest rates, at home and abroad, spelled an incipient recession; and it was all that was necessary to cause stockholders to revise their expectations.

The market drifted downwards in early October. As the volume of trading rose, brokerage firms were swamped, margin calls became more frequent and the ticker began to run behind. When prompt reporting of prires became impossible, investors lost track of their position. Panic selling began on Black Thursday and Black Tuesday. The vertical price drops forced margin calls on impaired accounts and led many others to liquidate their holdings. Although the frenzied selling occasionally abated, the market could not be talked up by bankers or by big investors' purchases of stock.

A more widespread financial crisis threatened as out-of-town banks and other lenders withdrew their loans to brokers. New York city banks stepped into the breach and quickly increased their loans. They were encouraged by the Federal Reserve Bank of New York, which made open market purchases and let its members know that they could borrow freely at the discount window. The direct financial effects of the crash were thus confined to the stock market. The New York Fed's prompt action ensured that there were no panic increases in money market rates and no threat to the banks from defaults on security loans.

This intelligent policy was the doing of the New York Fed; and, as Friedman and Schwartz (1963) have chronicled, the Board disapproved and censured New York. In spite of the recession, the Board maintained its tight money policy. The continued decline in the stock market after October 1929 in Figure 1 reflects the economy's policy-aggravated slide into depression. This contrasts the market's recovery in 1988 when no recession was in the making and the Board recognized the importance of monetary ease.

\section{Conclusion}

The technological and structural changes in industry in the 1920s promised higher earnings and dividends. While these developments created a stock market boom, they also made fundamentals more difficult to evaluate, thus setting the stage for a bubble. The October panic can be traced to early signs of a recession that made the dissonance between dividends and stock prices clear. When panic selling began, intervention by the Federal Reserve Bank of New York prevented a collapse of the financial system. This response was appropriate, but the same cannot be said for

\footnotetext{
${ }^{15}$ The peak of the business cycle has been dated from August 1929. The decline in all the Federal Reserve's indices came only when the October figures were published after the crash.
} 
earlier attempts to halt the market. Instead of allowing the stock market bubble to expand and burst of its own accord, the Federal Reserve's policies helped to push the economy further into a recession. Fear of a new speculative fever led the Federal Reserve Board to oppose easier monetary policy after the crash; hence, the tentative revival of the economy in 1930 was not assisted.

Although economists are generally skeptical about policy makers' ability to learn from history, the Federal Reserve did not make the same mistakes in 1987. In the months prior to the crash, the Fed was not preoccupied with speculation. When the collapse came, it followed the example of the New York Fed in 1929 and prevented a spillover to the banking system. Afterwards, it refocused its attention on general economic conditions. Spectacular as the crash of 1987 was, there was no reason for it to precipitate a second Great Depression.

The author wishes to thank Lawrence Fisher, James D. Hamilton, Hugh Rockoff, Anna J. Schwartz, Joseph Stiglitz, and Barrie A. Wigmore for helpful comments.

\section{References}

Allen, Frederick Lewis, Only Yesterday, An Informal History of the Nineteen-Twenties. New York: Harper and Row, 1931.

The Bankers' Magazine, London, 1929-1931.

Blanchard, Olivier J., and Mark W. Watson, "Bubbles, Rational Expectations, and Financial Markets." In Wachtel, Paul, ed., Crises in the Economic and Financial Structure. Lexington: D. C. Heath and Co., 1982, pp. 295-316.

Board of Governors of the Federal Reserve System, Banking and Monetary Statistics. Washington, D.C.: U.S. Government Printing Office, 1943.

Campbell, John Y., and Robert J. Shiller, "Stock Prices, Earnings and Expected Dividends," Journal of Finance, July 1988, 43, 661-676.

Carosso, Vincent P., Investment Banking in America, A History. Cambridge: Harvard University Press, 1970.

Chandler, Alfred D., Jr., The Visible Hand: The Managerial Revolution in American Business. Cambridge: Harvard University Press, 1977.

Clarke, Stephen V. O., Central Bank Cooperation, 1924-1931. New York: Federal Reserve Bank of New York, 1967.

Commercial and Financial Chronicle, New York, 1928 and 1929.

Currie, Lauchlin, "The Decline of the Commercial Loan," Quarterly Journal of Economics, Au- gust $1931,45,698-709$.

Crowther, Samuel, "Everybody Ought to be Rich," Ladies' Home Journal, August 1929.

Diba, Behzad T., and Herschel I. Grossman, "Explosive Rational Bubbles in Stock Prices?" American Economic Review, June 1988, 78, 520-530.

Dice, Charles Amos, New Levels in the Stock Market. New York: McGraw-Hill, 1929.

Eichengreen, Barry, "The Political Economy of the Smoot-Hawley Tariff," NBER Working Paper, August 1986.

Federal Reserve Bulletin, May 1931.

Field, Alexander J., "Asset Exchanges and the Transactions Demand for Money," American Economic Review, March 1984, 71, 43-59.

Fisher, Irving, The Stock Market Crash-and After. New York: Macmillan, 1930.

Fisher, Lawrence, "Some New Stock-Market Indexes," Journal of Business, 1966, 39, 191-225.

Friedman, Milton, and Anna J. Schwartz, A Monetary History of the United States, 1867-1960. Princeton: Princeton University Press, 1963.

Galbraith, John Kenneth, The Great Crash 1929. Boston: Houghton Mifflin Company, 1954 and 1988.

Hamilton, James D., "Monetary Factors in the Great Depression," Journal of Monetary Economics, 1987, 19, 145-169. 
Hamilton, James D., "On Testing for SelfFulfilling Speculative Price Bubbles," International Economic Review, October 1986, 27, 545-552.

Kindleberger, Charles P., Manias, Panics and Crashes: A History of Financial Crises. New York: Basic Books, 1978.

Kleidon, Allan W., "Variance Bounds Tests and Stock Price Valuation Models," Joumal of Political Economy, October 1986, 94, 953-1001.

Mankiw, N. Gregory, David Romer, and Matthew D. Shapiro, "An Unbiased Reexamination of Stock Market Volatility," Journal of Finance, July 1985, 9, 677-689.

Marsh, Terry A., and Robert C. Merton, "Dividend Behavior for the Aggregate Stock Market," Journal of Business, 1987, 60, 1-40.

McMullen, Frances D., "Women and the Ticker Tape-A Year after the Crash," The Women's Joumal, November 1930.

Neal, Larry D., "How the South Sea Bubble Was Blown Up and Burst." In White, Eugene N., ed., Crises and Panics: The Lessons of History. Homewood: Dow Jones-Irwin, 1990.

New York Stock Exchange, Year Book, 1930-1931, New York, 1931.

Patterson, Robert T., The Great Boom and Panic, 1921-1929. Chicago: Henry Regnery Company, 1965.

Peach, W. Nelson, The Security Affiliates of $\mathrm{Na}$ tional Banks. Baltimore: Johns Hopkins Press, 1941.

Pierce, Phyllis, ed., The Dow Jones Averages, 1885-1985. Homewood: Dow Jones-Irwin, 1986.

Romer, Christina, "The Great Crash and the Onset of the Great Depression," NBER Working Paper, June 1988.

Santoni, Gary, "The Great Bull Markets 1924-1929 and 1982-1987: Speculative Bubbles or Economic Fundamentals?" Federal Reserve Bank of St. Louis Review, November 1987, 69, 16-29.

Santoni, Gary, and Gerald P. Dwyer, Jr., "Bubbles vs Fundamentals: New Evidence from the Great Bull Markets." In White, Eugene N., ed., Crises and Panics: The Lessons of History. Homewood: Dow Jones/Irwin, 1989.
Shiller, Robert J., "Do Stock Prices Move Too Much to be Justified by Subsequent Changes in Dividends?" American Economic Review, June 1981, 71, 421-436.

Shiller, Robert J., and Pierre Perron, "Testing the Random Walk Hypothesis: Power versus Frequency of Observation," Economic Letters, 1985, 18, 381-386.

Sirkin, Gerald, "The Stock Market of 1929 Revisited: A Note," Business History Review, Summer 1975, 44, 223-31.

Smiley, Gene, and Richard H. Keehn, "Margin Purchases, Brokers' Loans and the Bull Market of the Twenties," Business and Economic History, 1988, 17, 129-142.

U.S. Department of Commerce, Historical Statistics of the United States, Colonial Times to 1970, Washington, D.C.: U.S. Government Printing Office, 1975.

Wanniski, Jude, The Way the World Works. New York: Basic Books, 1978.

West, Robert Craig, Banking Reform and the Federal Reserve, 1863-1923. Ithaca: Cornell University Press, 1977.

Wigmore, Barrie A., The Crash and Its Aftermath. Westport: Greenwood Press, 1985.

White, Eugene N., "Banking Innovation in the 1920s: The Growth of National Banks' Financial Services," Business and Economic History, 1984, 13, 92-104.

White, Eugene N., "Before the Glass-Steagall Act: An Analysis of the Investment Banking Activities of National Banks," Explorations in Economic History, January 1986, 23, 33-55.

White, Eugene N., "When the Ticker Ran Late: The Stock Market Boom and Crash of 1929." In White, Eugene N., ed., Crises and Panics: The Lessons of History. Homewood: Dow Jones/Irwin, 1990.

Wright, Ivan, "Loans to Brokers and Dealers for Account of Others," Journal of Business, April 1929, 2, 117-36. 
http://www.jstor.org

\title{
LINKED CITATIONS
}

- Page 1 of 4 -

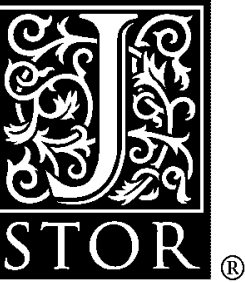

You have printed the following article:

\section{The Stock Market Boom and Crash of 1929 Revisited}

Eugene N. White

The Journal of Economic Perspectives, Vol. 4, No. 2. (Spring, 1990), pp. 67-83.

Stable URL:

http://links.jstor.org/sici?sici=0895-3309\%28199021\%294\%3A2\%3C67\%3ATSMBAC\%3E2.0.CO\%3B2-R

This article references the following linked citations. If you are trying to access articles from an off-campus location, you may be required to first logon via your library web site to access JSTOR. Please visit your library's website or contact a librarian to learn about options for remote access to JSTOR.

\section{[Footnotes]}

\author{
${ }^{4}$ The Decline of the Commercial Loan \\ Lauchlin Currie \\ The Quarterly Journal of Economics, Vol. 45, No. 4. (Aug., 1931), pp. 698-709. \\ Stable URL: \\ http://links.jstor.org/sici?sici=0033-5533\%28193108\%2945\%3A4\%3C698\%3ATDOTCL\%3E2.0.CO\%3B2-I

\section{${ }^{8}$ Dividend Behavior for the Aggregate Stock Market} \\ Terry A. Marsh; Robert C. Merton \\ The Journal of Business, Vol. 60, No. 1. (Jan., 1987), pp. 1-40. \\ Stable URL: \\ http://links.jstor.org/sici?sici=0021-9398\%28198701\%2960\%3A1\%3C1\%3ADBFTAS\%3E2.0.CO\%3B2-7
}

\footnotetext{
${ }^{12}$ Asset Exchanges and the Transactions Demand for Money, 1919-29

Alexander J. Field

The American Economic Review, Vol. 74, No. 1. (Mar., 1984), pp. 43-59.

Stable URL:

http://links.jstor.org/sici?sici=0002-8282\%28198403\%2974\%3A1\%3C43\%3AAEATTD\%3E2.0.CO\%3B2-X
}

\footnotetext{
${ }^{13}$ Explosive Rational Bubbles in Stock Prices?

Behzad T. Diba; Herschel I. Grossman

The American Economic Review, Vol. 78, No. 3. (Jun., 1988), pp. 520-530.

Stable URL:

http://links.jstor.org/sici?sici=0002-8282\%28198806\%2978\%3A3\%3C520\%3AERBISP\%3E2.0.CO\%3B2-V
}

NOTE: The reference numbering from the original has been maintained in this citation list. 
http://www.jstor.org

\title{
LINKED CITATIONS
}

- Page 2 of 4 -

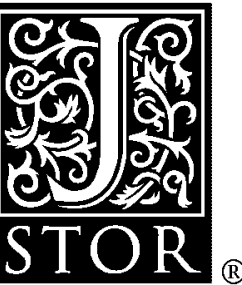

\footnotetext{
${ }^{13}$ Stock Prices, Earnings, and Expected Dividends

John Y. Campbell; Robert J. Shiller

The Journal of Finance, Vol. 43, No. 3, Papers and Proceedings of the Forty-Seventh Annual Meeting of the American Finance Association, Chicago, Illinois, December 28-30, 1987. (Jul., 1988), pp. 661-676.

Stable URL:

http://links.jstor.org/sici?sici=0022-1082\%28198807\%2943\%3A3\%3C661\%3ASPEAED\%3E2.0.CO\%3B2-1
}

\section{${ }^{13}$ Do Stock Prices Move Too Much to be Justified by Subsequent Changes in Dividends?} Robert J. Shiller

The American Economic Review, Vol. 71, No. 3. (Jun., 1981), pp. 421-436.

Stable URL:

http://links.jstor.org/sici?sici=0002-8282\%28198106\%2971\%3A3\%3C421\%3ADSPMTM\%3E2.0.CO\%3B2-2

\section{${ }^{13}$ An Unbiased Reexamination of Stock Market Volatility}

N. Gregory Mankiw; David Romer; Matthew D. Shapiro

The Journal of Finance, Vol. 40, No. 3, Papers and Proceedings of the Forty-Third Annual Meeting American Finance Association, Dallas, Texas, December 28-30, 1984. (Jul., 1985), pp. 677-687.

Stable URL:

http://links.jstor.org/sici?sici=0022-1082\%28198507\%2940\%3A3\%3C677\%3AAUROSM\%3E2.0.CO\%3B2-M

\author{
${ }^{13}$ Variance Bounds Tests and Stock Price Valuation Models \\ Allan W. Kleidon \\ The Journal of Political Economy, Vol. 94, No. 5. (Oct., 1986), pp. 953-1001. \\ Stable URL: \\ http://links.jstor.org/sici?sici=0022-3808\%28198610\%2994\%3A5\%3C953\%3AVBTASP\%3E2.0.CO\%3B2-M
}

\section{References}

\section{Stock Prices, Earnings, and Expected Dividends}

John Y. Campbell; Robert J. Shiller

The Journal of Finance, Vol. 43, No. 3, Papers and Proceedings of the Forty-Seventh Annual Meeting of the American Finance Association, Chicago, Illinois, December 28-30, 1987. (Jul., 1988), pp. 661-676.

Stable URL:

http://links.jstor.org/sici?sici=0022-1082\%28198807\%2943\%3A3\%3C661\%3ASPEAED\%3E2.0.CO\%3B2-1

NOTE: The reference numbering from the original has been maintained in this citation list. 
http://www.jstor.org

\section{LINKED CITATIONS}

- Page 3 of 4 -

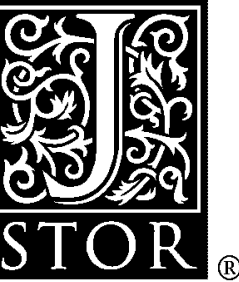

The Decline of the Commercial Loan

Lauchlin Currie

The Quarterly Journal of Economics, Vol. 45, No. 4. (Aug., 1931), pp. 698-709.

Stable URL:

http://links.jstor.org/sici?sici=0033-5533\%28193108\%2945\%3A4\%3C698\%3ATDOTCL\%3E2.0.CO\%3B2-I

\section{Explosive Rational Bubbles in Stock Prices?}

Behzad T. Diba; Herschel I. Grossman

The American Economic Review, Vol. 78, No. 3. (Jun., 1988), pp. 520-530.

Stable URL:

http://links.jstor.org/sici?sici=0002-8282\%28198806\%2978\%3A3\%3C520\%3AERBISP\%3E2.0.CO\%3B2-V

Asset Exchanges and the Transactions Demand for Money, 1919-29

Alexander J. Field

The American Economic Review, Vol. 74, No. 1. (Mar., 1984), pp. 43-59.

Stable URL:

http://links.jstor.org/sici?sici=0002-8282\%28198403\%2974\%3A1\%3C43\%3AAEATTD\%3E2.0.CO\%3B2-X

\section{Some New Stock-Market Indexes}

Lawrence Fisher

The Journal of Business, Vol. 39, No. 1, Part 2: Supplement on Security Prices. (Jan., 1966), pp.

191-225.

Stable URL:

http://links.jstor.org/sici?sici=0021-9398\%28196601\%2939\%3A1\%3C191\%3ASNSI\%3E2.0.CO\%3B2-A

\section{On Testing for Self-Fulfilling Speculative Price Bubbles}

James D. Hamilton

International Economic Review, Vol. 27, No. 3. (Oct., 1986), pp. 545-552.

Stable URL:

http://links.jstor.org/sici?sici=0020-6598\%28198610\%2927\%3A3\%3C545\%3AOTFSSP\%3E2.0.CO\%3B2-7

\section{Variance Bounds Tests and Stock Price Valuation Models}

Allan W. Kleidon

The Journal of Political Economy, Vol. 94, No. 5. (Oct., 1986), pp. 953-1001.

Stable URL:

http://links.jstor.org/sici?sici=0022-3808\%28198610\%2994\%3A5\%3C953\%3AVBTASP\%3E2.0.CO\%3B2-M

NOTE: The reference numbering from the original has been maintained in this citation list. 
http://www.jstor.org

\section{LINKED CITATIONS \\ - Page 4 of 4 -}

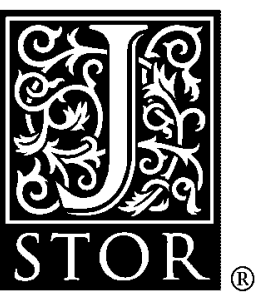

\section{An Unbiased Reexamination of Stock Market Volatility}

N. Gregory Mankiw; David Romer; Matthew D. Shapiro

The Journal of Finance, Vol. 40, No. 3, Papers and Proceedings of the Forty-Third Annual Meeting American Finance Association, Dallas, Texas, December 28-30, 1984. (Jul., 1985), pp. 677-687.

Stable URL:

http://links.jstor.org/sici?sici=0022-1082\%28198507\%2940\%3A3\%3C677\%3AAUROSM\%3E2.0.CO\%3B2-M

\section{Dividend Behavior for the Aggregate Stock Market}

Terry A. Marsh; Robert C. Merton

The Journal of Business, Vol. 60, No. 1. (Jan., 1987), pp. 1-40.

Stable URL:

http://links.jstor.org/sici?sici=0021-9398\%28198701\%2960\%3A1\%3C1\%3ADBFTAS\%3E2.0.CO\%3B2-7

\section{Do Stock Prices Move Too Much to be Justified by Subsequent Changes in Dividends?}

Robert J. Shiller

The American Economic Review, Vol. 71, No. 3. (Jun., 1981), pp. 421-436.

Stable URL:

http://links.jstor.org/sici?sici=0002-8282\%28198106\%2971\%3A3\%3C421\%3ADSPMTM\%3E2.0.CO\%3B2-2

NOTE: The reference numbering from the original has been maintained in this citation list. 